\title{
Polymorphisms in CYP2E1, GSTM1 and GSTT1 and anti-tuberculosis drug-induced hepatotoxicity
}

\author{
TAIS C. BRITO ${ }^{1}$, LIA G. POSSUELO ${ }^{2}$, ANDREIA R.M. VALIM ${ }^{2}$, PÂMELA F. TODENDI ${ }^{2}$, \\ ANDREZZA W. RIBEIRO ${ }^{3}$, TATIANA S. GREGIANINI ${ }^{3}$, CARLA A. JARCZEWSKI ${ }^{4}$, \\ MARA H. HUTZ ${ }^{5}$, MARIA LUCIA R. ROSSETTI ${ }^{6}$ and ARNALDO ZAHA ${ }^{6}$ \\ ${ }^{1}$ Programa de Pós-Graduação em Biologia Celular e Molecular, Departamento de Biologia Molecular e Biotecnologia, \\ Instituto de Biociências, Centro de Biotecnologia, Universidade Federal do Rio Grande do Sul/UFRGS, \\ 91501-970 Porto Alegre, RS, Brasil \\ ${ }^{2}$ Programa de Pós-Graduação em Promoção da Saúde, Universidade de Santa Cruz do Sul, \\ Av. Independência, 2293, 96815-900 Santa Cruz do Sul, RS, Brasil \\ ${ }^{3}$ Centro de Desenvolvimento Científico e Tecnológico, Fundação Estadual de Produção e Pesquisa em Saúde, \\ Avenida Ipiranga, 5400, 90610-000 Porto Alegre, RS, Brasil \\ ${ }^{4}$ Hospital Sanatório Partenon, Avenida Bento Gonçalves, 3722, Bairro Partenon, 90640-003 Porto Alegre, RS, Brasil \\ ${ }^{5}$ Departamento de Genética, Universidade Federal do Rio Grande do Sul/UFRGS, \\ Avenida Bento Gonçalves, 9500, Prédio 43323, 91501-970 Porto Alegre, RS, Brasil \\ ${ }^{6}$ Departamento de Biologia Molecular e Biotecnologia, IB e Centro de Biotecnologia, \\ Universidade Federal do Rio Grande do Sul, Avenida Bento Gonçalves, 9500, Prédio 43421, 91501-970 Porto Alegre, RS, Brasil
}

Manuscript received on August 29, 2013; accepted for publication on February 17, 2014

\begin{abstract}
Anti-tuberculosis drug-induced hepatitis (ATD- induced hepatitis) has been linked to polymorphisms in genes encoding drug metabolizing enzymes. $N$-acetyltransferase 2 (NAT2), cytochrome P450 2E1 (CYP2E1) and glutathione $S$-transferase (loci GSTM1 and GSTT1) are involved in the metabolism of isoniazid, the most toxic drug for the treatment of tuberculosis (TB). This study was designed to determine the frequency and to evaluate whether polymorphisms at CYP2E1, GSTM1 and GSTT1 genes are associated with drug response, as well as to identify clinical risk factors for ATD-induced hepatitis. A total of 245 Brazilian patients undergoing treatment for TB were genotyped using polymerase chain reaction and restriction fragment length polymorphism and sequencing methods. The frequencies of the CYP2E1 polymorphic alleles RsaI, PstI and DraI are $8 \%, 8.5 \%$ and $12 \%$, respectively. GSTM1 and GSTT1 genes are deleted in $42.9 \%$ and $12.4 \%$ of the population, respectively. Fifteen patients $(6.1 \%)$ developed hepatotoxicity. Clinical (HIV, female sex and extrapulmonary TB) and genetic characteristics (CYP2E1 without any mutations, having NAT2 slow acetylator profile) are at higher risk of developing ATD-induced hepatitis in this population. Genotyping for GSTM1 and GSTT1 showed no influence on drug response.
\end{abstract}

Key words: hepatotoxicity, isoniazid, polymorphisms, tuberculosis.

Correspondence to: Arnaldo Zaha

E-mail: zaha@cbiot.ufrgs.br 


\section{INTRODUCTION}

Anti-tuberculosis drug-induced hepatitis (ATDinduced hepatitis) is an important clinical problem, being the most severe adverse effect during tuberculosis (TB) treatment (Tostmann et al. 2008, Walker et al. 2009, Cai et al. 2012). Currently, the 6-month therapy consists in the combination of the drugs isoniazid (INH), rifampicin (RMP), pyrazinamide (PZA) and ethambutol (EMB) (Stine et al. 2013). The last one was added to the Brazilian first-line therapy in 2009 (Conde et al. 2009). Patients often suffer adverse drug reactions (ADR) and it is of increasing concern the fact that hepatotoxicity may be due to additive or synergistic effects of INH and RMP (Yew and Leung, 2006). The frontline drug, INH, has been extensively studied (Cheng et al. 2013). In the human liver, INH is first acetylated by $\mathrm{N}$-acetyltransferase 2 (NAT2) into acetylhydrazine, then oxidized into toxic intermediaries by cytochrome P450 2E1 (CYP2E1) (Huang et al. 2003, Chamorro et al. 2013). The toxic compounds produced are detoxified by further acetylation by NAT2 and by conjugation reactions catalyzed by glutathione $S$-transferase enzymes (GST). Frequency and severity of anti-TB druginduced hepatotoxicity is variable and unpredictable. Secondary pathways and the metabolizing profile take part in the unbalance between hepatotoxin production and liver detoxification (Roy et al. 2001, Leiro et al. 2008). Our previous study of NAT2 polymorphism demonstrated that a slow acetylation profile is associated to ATD-induced hepatitis (Possuelo et al. 2008).

Risk factors for ATD-induced hepatitis, such as HIV, hepatitis B and C coinfection, elevated baseline transaminases, older age and female sex (FernándezVillar et al. 2004, Saukkonen et al. 2006, Possuelo et al. 2008, Yimer et al. 2011), are usually implicated, but seem to vary among populations.

Genetic factors can also have a large influence on drug response. Enzymes from cytochrome P450 (CYP) are responsible for about $80 \%$ of all phase I drug metabolism (Eichelbaum et al.
2006). CYP genes are highly polymorphic and the polymorphisms have been associated with altered gene expression and drug adverse reactions (Ingelman Sundberg, 2004, Ingelman Sundberg et al. 2007). Polymorphisms in CYP2E1 have been investigated in relation to alcoholism, chronic obstructive pulmonary disease, alcoholic liver cirrhosis, innumerous types of cancer and ATDinduced hepatitis (Kato et al. 1992, Arif et al. 2007, Boccia et al. 2007, Cho et al. 2007, Liu et al. 2007, Khan et al. 2009).

In addition to CYP2E1, GSTM1 and GSTT1 enzymes are also involved in the detoxification pathway of INH toxic metabolites. Deficiency in GST activity caused by gene deletion may modulate susceptibility to drug and xenobioticinduced hepatotoxicity (Roy et al. 2001).

Genetic-environmental factors differ among individuals and populations. The characterization and study of the geographical distribution of human genetic diversity is crucial for the understanding of human genomic variations. The interethnic admixture observed in the Americas makes these populations especially valuable for a pharmacogenomics approach (Suarez-Kurtz and Pena 2006).

This study was designed to determine the frequency and to evaluate whether polymorphisms at CYP 2E1, GSTM1 and GSTT1 genes are associated with drug response, as well as to identify clinical risk factors for hepatotoxicity, in a population undergoing treatment for TB with isoniazid, rifampicin and pyrazinamide (RHZ) from the city of Porto Alegre, state of Rio Grande do Sul, Brazil.

\section{MATERIALS AND METHODS}

\section{STUDY POPULATION}

This prospective study was carried out between August 2005 and August 2007 and 245 unrelated patients with newly diagnosed TB from the outpatient section of Hospital Sanatório Partenon (HSP), a public TB reference hospital located in Porto Alegre 
(Rio Grande do Sul), were consecutively selected for the study. Inclusion criteria were: patients aged 18 years and older that were newly diagnosed with active $\mathrm{TB}$ and were submitted to a daily treatment with INH, RMP, and PZA for the first 2 months, followed by INH and RMP for an additional 4 months. Exclusion criteria were: patients using anti-TB drugs prior to study enrollment, patients whose results of liver function tests prior to the beginning of treatment were higher than twice the upper limit considered normal (ULN) and refusal to participate in the study. Details about treatment, liver function tests and serology for Hepatitis C virus (HCV), Hepatitis B virus (HBV) and Human immunodeficiency virus (HIV) are described in Possuelo et al, 2008. Criteria for the diagnosis of ATD-induced hepatitis was an elevation in liver function tests, aspartate aminotransferase (AST) and/or alanine aminotransferase (ALT) of more than threefold the ULN (reference values: 40 and $65 \mathrm{U} / \mathrm{L}$, respectively) and/or total bilirubin up to $>2.0 \mathrm{mg} / \mathrm{dL}$ in the presence of gastrointestinal symptoms such as anorexia, nausea, vomiting and/or jaundice, with serum ALT level normalization after anti-TB drug discontinuation. These criteria are routinely used by pneumologists and gastroenterologists of HSP and are consistent with the recommendations of the Brazilian Tuberculosis Consensus (Castelo Filho et al. 2004). Hepatotoxicity analysis based on the criteria of the International Consensus meeting (Bénichou 1990) (ALT higher than twofold the ULN) for drug-induced hepatotoxicity was also carried out. Clinical and epidemiological data, such as age, sex, skin color (self-reported), alcohol abuse (according to CAGE criteria Mayfield et al. 1974), and use of highlyactive antiretroviral therapy (HAART) or another co-medication, were collected using a standardized questionnaire at an interview and the review of medical records of each patient.

The protocol used in the present study was approved by the Research Ethics Committee of the School of Public Health, state of Rio Grande do Sul (protocol number 156/05) and by the Fundação
Estadual de Produção e Pesquisa em Saúde- FEPPS (protocol number 18/2006). All patients recruited in the present study signed a written informed consent form. We declare that the experiments comply with current Brazilian laws.

\section{CYP2E1, GSTM1,GSTT1 and NAT2 GENOTYPING}

Genomic DNA was extracted from a whole blood sample of each patient according to the Salting Out method, modified from Miller et al. (Miller et al. 1988). Polymorphisms in CYP2E1 were detected using the polymerase chain reaction-restriction fragment length polymorphism (PCR-RFLP) method (Molecular Probes, Invitrogen Detection Technologies, OR, USA). Amplification was performed in a PTC- $100^{\mathrm{TM}}$ thermocycler (MJ Research Inc) and PCR details are described in Supplementary Table I. After amplification, the fragment was digested with RsaI (5U New England BioLabs) and PstI (4U, Invitrogen, Brazil) endonucleases, at positions $-1053 \mathrm{C}>\mathrm{T}$ and $-1293 \mathrm{G}>\mathrm{C}$, respectively. A region in intron 6 of CYP2E1 (7632T $>$ A) was amplified and digested with DraI (8U, New England BioLabs). Wild type CYP2E1 allele $(* 1 \mathrm{~A})$ has restriction sites for RsaI and DraI, but not for PstI. The presence of restriction sites yielded two fragments of 352 and $143 \mathrm{bp}$ for $R s a \mathrm{I}$ restriction digest, 377 and 118 for PstI, and 268 and 306 for DraI restriction digest. Digested products were analyzed by electrophoresis in $2.5 \%$ agarose gel and stained with ethidium bromide or GelRed ${ }^{\mathrm{TM}}$. Presence or absence of GSTM1 and GSTT1 were observed by performing two multiplex PCRs. NAT2 genotyping method was described by Possuelo et al. (Possuelo et al. 2008).

GSTT1 amplification was performed using two different primers due to the frequency of gene deletion that was unexpectedly lower than that usually observed in other populations. For the second analysis, primers designed by other authors were used (Leiro et al. 2008). GSTs were considered present when the fragment was amplified together 
TABLE I

Description of all Anti Tuberculisis Drug-induced hepatitis cases.

\begin{tabular}{ccccccc}
\hline Case & Sex & Time (days) $^{\mathbf{a}}$ & Age (years) & Bilirubin peak (mg/dL) & AST/ALT Peak (U/L) & Risk factors $^{\mathbf{b}}$ \\
\hline 1 & $\mathrm{~F}$ & 13 & 27 & 0.60 & $148 / 705$ & 1 \\
2 & $\mathrm{M}$ & 15 & 66 & 1.5 & $857 / 548$ & - \\
3 & $\mathrm{~F}$ & 17 & 38 & 0.72 & $233 / 429$ & $1,3,5$ \\
4 & $\mathrm{M}$ & 14 & 31 & 1.05 & $275 / 503$ & $2,3,5$ \\
5 & $\mathrm{~F}$ & 11 & 42 & 4.56 & $75 / 318$ & 1 \\
6 & $\mathrm{~F}$ & 11 & 49 & 3.72 & $96 / 398$ & $1,3,4$ \\
7 & $\mathrm{M}$ & 14 & 44 & 1.09 & $62 / 309$ & 3 \\
8 & $\mathrm{M}$ & 13 & 37 & 1.6 & $157 / 197$ & 3,4 \\
9 & $\mathrm{~F}$ & 14 & 19 & 1.35 & $134 / 406$ & 1 \\
10 & $\mathrm{M}$ & 8 & 30 & 1.6 & $153 / 254$ & 3,4 \\
11 & $\mathrm{~F}$ & 8 & 51 & 0.82 & $316 / 392$ & 1,2 \\
12 & $\mathrm{M}$ & 17 & 46 & 0.61 & $234 / 804$ & 3 \\
13 & $\mathrm{M}$ & 13 & 25 & 0.42 & $339 / 188$ & \\
14 & $\mathrm{~F}$ & 90 & 25 & 1.61 & $221 / 492$ & 1,3 \\
15 & $\mathrm{~F}$ & 5 & 27 & 0.69 & $93 / 85$ & 1 \\
\hline
\end{tabular}

${ }^{a}$ Time until diagnosis of hepatotoxicity. ${ }^{b}$ Risk factors: 1) female sex, 2) Hepatitis C Virus, 3) Human immunodeficiency virus (HIV), 4) Highly active antiretroviral therapy (HAART), 5) alcohol abuse. $\mathrm{F}=$ female; $\mathrm{M}=$ male; AST= aspartate transaminase; $\mathrm{ALT}=$ alanine transaminase; Peak= highest level during treatment.

with the 560 bp NAT2 DNA fragment, used as an internal control. When only the NAT2 fragment was detected in the gel, GST was considered as a deleted gene.

\section{STATISTICAL ANALYSES}

Allele frequencies at individual SNPs were estimated by means of counting. Linkage disequilibrium $(D)$ and $D^{\prime}$ (the relative magnitude of $\mathrm{D}$ as compared to its theoretical maximum) were also calculated using the software program MULTIPLE LOCUS HAPLOTYPE ANALYSIS release 2.0 (Multiple Locus Haplotype Analysis 1999, Long et al.1995).

All statistical analyses were performed using the SPSS statistical program, release 12.0 (SPSS, Chicago, IL). Values are expressed as means \pm standard deviation (SD) or as numbers and percentages. Group comparisons for categorical variables were carried out using the $\chi^{2}$ test, while Student's $t$ test was used for the analysis of continuous variables. Relative risk (RR) and confidence intervals $(\mathrm{CI}=95 \%)$ were calculated. Multiple logistic regression analyses were carried out using the backward model. All statistical tests were based on two-tailed probability and a $\mathrm{p}$ value $\leq 0.05$ was considered significant. The multivariate model was generated using variables with a $p$ value $<0.20$.

\section{RESULTS}

\section{PATIENTS CHARACTERISTICS}

Fifteen patients $(6.1 \%)$ developed ATD-induced hepatitis (Table I). All of them have had their treatment switched to streptomycin (SM), INH and $\mathrm{EMB}$, an alternative treatment to RMP, INH and PZAHZ used in Rio Grande do Sul in the presence of ATD-induced hepatitis. None of the patients had a new episode of hepatotoxicity with the new regimen. Co-medication during TB treatment was used by 100 patients $(40.8 \%)$. Of the 64 HIVpositive patients, 33 (51\%) used co-medication and 3 of them developed hepatotoxicity (9\%). ADR during treatment was observed in 48 (19.6\%) patients. In the present study, only the mean AST and ALT values at baseline differed considerably between patients with and without ATD-induced hepatitis (Table II). 


\section{GENOTYPING ANALYSIS}

Regarding the polymorphisms in CYP2E1 at position $-1053,210(85.7 \%)$ patients were genotyped as $* 1 \mathrm{~A} / * 1 \mathrm{~A}$ (wild-type), $31(12.7 \%) * 1 \mathrm{~A} / * 5 \mathrm{~B}$ (heterozygous) and $4(1.6 \%) * 5 \mathrm{~B} / * 5 \mathrm{~B}$ (mutant). At position $-1293,208(84.9 \%)$ were $* 1 \mathrm{~A} / * 1 \mathrm{~A}$ (wildtype), $32(13.1 \%) * 1 \mathrm{~A} / * 5 \mathrm{~B}$ (heterozygous) and 5 $(2 \%) * 5 B / * 5 B$ (mutant). For polymorphism in intron 6, $191(78 \%)$ patients were genotyped as $* 1 \mathrm{~A} / * 1 \mathrm{~A}$ (wild-type), $49(20 \%) * 1 \mathrm{~A} / * 6$ (heterozygous) and $5(2 \%) * 6 / * 6$ (mutant). The GSTM1 null mutation was found in 105 patients (42.9\%) and GSTT1 null genotype in 30 patients $(12.2 \%)$. The most frequent NAT2 genotypes were $* 5 / 12(31.3 \%),{ }^{*} 12 / 12(15 \%)$, $* 5 / 5(12.2 \%), 6 / 6(8.1 \%)$ and $4 / 4(6.1 \%)$. The results of a linkage disequilibrium test carried out with CYP2E1 SNPs are shown in Supplemantary Table II.

TABLE II

Univarite analysis of clinical risk factors for ATD- induced hepatitis.

\begin{tabular}{|c|c|c|c|c|}
\hline & \multicolumn{2}{|c|}{ Hepatotoxicity } & \multirow{2}{*}{ Total } & \multirow{2}{*}{$p$} \\
\hline & Yes & No & & \\
\hline $\begin{array}{l}\text { Mean Age } \\
\quad( \pm \text { SD })\end{array}$ & $\begin{array}{c}38.1 \\
( \pm 12.79)\end{array}$ & $\begin{array}{c}36.8 \\
( \pm 12.8)\end{array}$ & $\begin{array}{c}36.8 \\
( \pm 12.8)\end{array}$ & 0.7 \\
\hline $\begin{array}{c}\mathrm{BMI} \\
\left(\mathrm{kg} / \mathrm{m}^{2}\right)\end{array}$ & $\begin{array}{c}21.3 \\
( \pm 3.1)\end{array}$ & $\begin{array}{l}20.7 \\
( \pm 3.3)\end{array}$ & $\begin{array}{c}20.7 \\
( \pm 3.2)\end{array}$ & 0.2 \\
\hline $\begin{array}{l}\text { AST (U/L) } \\
\text { baseline }\end{array}$ & $\begin{array}{c}41.9 \\
( \pm 36.2)\end{array}$ & $\begin{array}{l}26.5 \\
( \pm 16)\end{array}$ & $\begin{array}{c}28.1 \\
( \pm 20.3)\end{array}$ & 0.007 \\
\hline $\begin{array}{l}\text { ALT (U/L) } \\
\text { baseline }\end{array}$ & $\begin{array}{c}40.5 \\
( \pm 32.6)\end{array}$ & $\begin{array}{c}28,6 \\
( \pm 19.1)\end{array}$ & $\begin{array}{c}29.8 \\
( \pm 20.1)\end{array}$ & 0.04 \\
\hline $\begin{array}{l}\text { Total bilirubin } \\
\text { (mg/dL) baseline }\end{array}$ & $\begin{array}{c}0.5 \\
( \pm 0.18)\end{array}$ & $\begin{array}{c}0.4 \\
( \pm 0.28)\end{array}$ & $\begin{array}{c}0.4 \\
( \pm 0.27)\end{array}$ & 0.6 \\
\hline AST (U/L) peak & $\begin{array}{c}187.9 \\
( \pm 89.3)\end{array}$ & $\begin{array}{c}37.8 \\
( \pm 78.9)\end{array}$ & $\begin{array}{c}52.6 \\
( \pm 91.4)\end{array}$ & $<0.001$ \\
\hline ALT (U/L) peak & $\begin{array}{c}419.8 \\
( \pm 182.9)\end{array}$ & $\begin{array}{c}43.5 \\
( \pm 54.8)\end{array}$ & $\begin{array}{c}80.5 \\
( \pm 135.8)\end{array}$ & $<0.001$ \\
\hline $\begin{array}{l}\text { Total bilirubin } \\
(\mathrm{mg} / \mathrm{dL}) \text { peak }\end{array}$ & $\begin{array}{c}1.2 \\
( \pm 0.9)\end{array}$ & $\begin{array}{c}0.4 \\
( \pm 0.6)\end{array}$ & $\begin{array}{c}0.47 \\
( \pm 0.7)\end{array}$ & $<0.001$ \\
\hline
\end{tabular}

SD - stand deviation; BMI - body mass index; AST- Aspartate transaminase; ALT- Alanine transaminase; peak- the highest level after commencing the treatment.

\section{ASSOCIATION AMONG CLINICAL FACTORS, GENOTYPES AND} ATD-INDUCED HEPATITIS

Of the 15 patients with ATD-induced hepatitis, none were homozygous mutant for CYP2E1 and only one had both GST genes deleted. In these patients, no difference was observed regarding polymorphism frequencies in relation to all patients.

Combined analysis of the polymorphisms in CYP2E1, GSTM1 and GSTT1 genes was performed, but no synergistic effect was observed. When the NAT2 slow phenotype was combined with CYP2E1 $R s a \mathrm{I} * 1 \mathrm{~A} / * 1 \mathrm{~A}$ genotype, the association with hepatotoxicity was stronger (Table III).

Analysis of liver function tests before the start of the treatment showed that $13 \%$ of patients had AST levels higher than the ULN, 6.2\% had altered AST levels and 1.2\% had bilirubin alteration. Among patients with altered AST levels before treatment, $25 \%$ were 3 -fold or more above the normal limit. Comparative analysis using mean baseline ALT and AST and GSTM1, CYP2E1, GSTT1 and NAT2 genotypes was performed and no significant differences were observed. AST, ALT and total bilirubin levels after 30 days of treatment were significantly higher in patients homozygous (wild type) for the $R s a I^{*} 1 \mathrm{~A}$ allele $(\mathrm{p}<0.05)$.

After performing multivariate analysis, HIV, female sex, hepatotoxicity and NAT2 slow acetylator were significantly associated with hepatotoxicity in this population (Table IV).

\section{DISCUSSION}

Our study shows the frequency of polymorphisms in CYP2E1, GSTM1 and GSTT1, their association with ATD-induced hepatitis and clinical risk factors. The main finding in the present study is that the association between genotype and hepatotoxicity is only observed when it includes NAT2 slow acetylator. In a study carried out in Brazil, the NAT2, CYP2E1, GSTM1 and GSTT1 polymorphisms were genotyped with regimens containing INH, where slow acetylators had a higher incidence of ATDinduced hepatitis than intermediate acetylators. The logistic regression showed that slow acetylation was a risk factor for drug-induced hepatotoxicity (OR 3.59, 95\% CI, 2.53-4.64, p = 0.02) (Teixeira 
TABLE III

Genotype and allelic characterization of the CYP2E1, GSTM1, GSTT1 and acetylation profile of NAT2 in tuberculosis patients with and without hepatotoxicity.

\begin{tabular}{|c|c|c|c|c|c|}
\hline & \multicolumn{2}{|c|}{ Hepatotoxicity } & \multirow[b]{2}{*}{ Total } & \multirow[b]{2}{*}{$\mathbf{p}$} & \multirow[b]{2}{*}{ OR (95\%IC) } \\
\hline & $\begin{array}{c}\text { Yes } \\
\mathrm{N}=15(\%)\end{array}$ & $\begin{array}{c}\text { No } \\
\mathbf{N}=\mathbf{2 3 0}(\%)\end{array}$ & & & \\
\hline 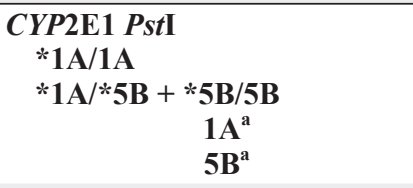 & $\begin{array}{c}13(86.7) \\
2(13.3) \\
28(6.2)^{\mathrm{b}} \\
2(4.8)^{\mathrm{b}}\end{array}$ & $\begin{array}{c}195(84.8) \\
35(15.2) \\
420(93.8)^{\mathrm{c}} \\
40(95.2)^{\mathrm{c}}\end{array}$ & $\begin{array}{c}208(84.9) \\
37(15.1) \\
448(91.4)^{d} \\
42(8.6)^{d}\end{array}$ & 1.0 & $0.85(0.18-3.56)$ \\
\hline $\begin{array}{l}\text { CYP2E1 RsaI } \\
* 1 \mathrm{~A} / 1 \mathrm{~A} \\
\begin{aligned} & * 1 \mathrm{~A} / * 5 \mathrm{~B}+ * 5 \mathrm{~B} / 5 \mathrm{~B} \\
& 1 \mathrm{~A}^{\mathrm{a}} \\
& 5 \mathrm{~B}^{\mathrm{a}}\end{aligned}\end{array}$ & $\begin{array}{c}14(93.3) \\
1(6.7) \\
29(7.0)^{b} \\
1(2.6)^{b}\end{array}$ & $\begin{array}{c}196(85.2) \\
34(14.8) \\
422()^{\mathrm{c}} \\
38(97.4)^{\mathrm{c}}\end{array}$ & $\begin{array}{c}210(85.7) \\
35(14.3) \\
451(92.0)^{\mathrm{d}} \\
39(8.0)^{\mathrm{d}}\end{array}$ & 0.7 & $0.41(0.05-3.23)$ \\
\hline $\begin{array}{l}\text { CYP2E1 DraI } \\
* 1 \mathrm{~A} / 1 \mathrm{~A} \\
\begin{array}{l}* 1 \mathrm{~A} / * 6+* 6 / 6 \\
1 \mathrm{~A}^{\mathrm{a}} \\
6^{\mathrm{a}}\end{array}\end{array}$ & $\begin{array}{c}12(80) \\
3(20) \\
27(6.3)^{\mathrm{b}} \\
3(5.1)^{\mathrm{b}}\end{array}$ & $\begin{array}{c}179(77,8) \\
51(22.2) \\
404(93.7)^{\mathrm{c}} \\
56(94.9)^{\mathrm{c}}\end{array}$ & $\begin{array}{c}191(78) \\
54(22) \\
431(88.0)^{\mathrm{d}} \\
59(22.0)^{\mathrm{d}}\end{array}$ & 1.0 & $0.83(0.22-3.06)$ \\
\hline GSTM1 null & $6(40)$ & $99(43)$ & $105(42.9)$ & 1.0 & $0.88(0.30-2.56)$ \\
\hline GSTT1 null & $2(13.3)$ & $28(12.2)$ & $30(12.4)$ & 1.0 & $1.1(0.23-5.17)$ \\
\hline GSTM1 + GSTT1 null & $1(6.7)$ & $12(5.2)$ & $13(5.3)$ & 0.57 & $1.3(0.15-10.7)$ \\
\hline NAT2 slow & $9(60)$ & $56(24.3)$ & $65(26.5)$ & 0.03 & $5.46(1.75-16.98)$ \\
\hline NAT2 slow + GSTM1null & $2(13.3)$ & $46(20)$ & $48(19.6)$ & 0.7 & $0.6(0.13-2.8)$ \\
\hline NAT2 slow + CYP RsaI*1A & $9(60)$ & $49(21.3)$ & $58(23.7)$ & 0.002 & $5.5(1.88-16.3)$ \\
\hline $\begin{array}{l}\text { NAT2 slow + CYP RsaI*1A + } \\
\text { CYP PstI*1A + CYP DraI*1A }\end{array}$ & $7(46.7)$ & $43(18.7)$ & $50(20.4)$ & 0.017 & $3.8(3.3-11.06)$ \\
\hline
\end{tabular}

${ }^{a}$ Allelic frequency; ${ }^{b}$ Frequency refers to 460 alleles; ${ }^{c}$ Frequency refers to 30 alleles; ${ }^{d}$ Frequency refers to 490 alleles; OR odds ratio; CI- confidence interval; NAT2- N-acetyltransferase 2; GSTT1- glutathione S-transferase T1; GSTM1- glutathione $S$-transferase M1; CYP- cytochrome P450.

et al. 2011). NAT2 is one of the factors responsible for genetic predisposition to INH-induced hepatitis and NAT2 acetylating status is related to the patient's condition, sex and ethnic origin, so it may be regarded as important risk factor for the development of hepatotoxicity (Mahmoud et al. 2012, Chamorro et al. 2013).

Many studies reported the two polymorphisms in the 5' flanking region of CYP2E1 as being in complete linkage disequilibrium (LD). In our study, similar to the results described by Kato et al (1992), RsaI and PstI polymorphisms were not in total LD. Five patients did not have those polymorphisms linked in LD: 3 were $R s a \mathrm{I} * 1 \mathrm{~A} / * 1 \mathrm{~A}$ and Pst $\mathrm{I} * 1 \mathrm{~A} / * 5 \mathrm{~B}$; one was $R s a \mathrm{I}$ $* 1 \mathrm{~A} / * 5 \mathrm{~B}$ and $P s t \mathrm{I} * 1 \mathrm{~A} / * 1 \mathrm{~A}$ and one was $R s a \mathrm{I}$
$* 1 \mathrm{~A} / * 5 \mathrm{~B}$ and Pst $\mathrm{I} * 5 \mathrm{~B} / * 5 \mathrm{~B}$. Earlier reports showed that the mutant allele $* 5 \mathrm{~B}$ was associated with higher transcriptional activity, protein levels and enzyme activity than the common wild type allele *1A (Hayashi et al. 1991, Watanabe et al. 1994). However, opposing data have been reported in more recent studies (An et al. 2012, Huang et al. 2003). In the population studied by Huang and cols, wild-type patients $\left(* 1 \mathrm{~A} /{ }^{*} 1 \mathrm{~A}\right)$ were at increased risk for ATD-induced hepatitis (Huang et al. 2003). Vuilleumier et al. reported a significant association between the wild-type CYP2E1 and elevated liver enzymes. Nevertheless they did not observe a significant association between INH-induced hepatitis and CYP2E1 genotypes (Vuilleumier et al. 2006). The CYP2E1 wild-type 
TABLE IV

Multivariate logistic analysis of risk factors associated with the development of hepatotoxicity.

\begin{tabular}{ccccc}
\hline Characteristic & $\begin{array}{c}\text { Bivariate analysis: } \\
\text { odds ratio (95\% CI) }\end{array}$ & $\boldsymbol{p}$ & $\begin{array}{c}\text { Multivariate analysis: } \\
\text { odds ratio (95\% CI) }\end{array}$ & $\boldsymbol{p}$ \\
\hline HCV positive & $0.71(0.15-3.3)$ & 0.5 & ------ & - \\
Alcohol use & $0.8(0.17-3.7)$ & 1.0 & ---- & \\
White skin color & $0.5(0.14-1.5)$ & 0.3 & ----- & \\
Co-medication & $0.96(0.33-2.80)$ & 1.0 & $0.39(0.01-11.28)$ & 0.58 \\
AST baseline & $3.4(0.99-12.07)$ & 0.06 & $18.04(0.50-640.0)$ & 0.11 \\
ALT baseline & $3.020 .60-17.07$ & 0.18 & $2.12(0.18-247.8)$ & 0.75 \\
HBV positive & $5.4(0.52-55.6)$ & 0.2 & $1.64(0.25-10.65)$ & 0.60 \\
HAART & $3.13(1.6-13.7)$ & 0.1 & $6.46(1.20-36.68)$ & 0.01 \\
HIV positive & $3.5(1.23-10.2)$ & 0.03 & $5.9(1.22-28.76)$ & 0.02 \\
Female & $0.43(0.15-1.23)$ & 0.2 & $5.1(1.0923 .83)$ & 0.03 \\
Extrapulmonary TB & $3.8(1.3-11.5)$ & 0.02 & $14.59(2.92-72.74)$ & 0.001 \\
\hline Slow acetylator profile - NAT2 & $5.46(1.75-16.98)$ & 0.03 & & \\
\hline
\end{tabular}

HAART- Highly active antiretroviral therapy; HIV- Human immunodeficiency virus; HC(B)V-Hepatitis C(B) virus; CI- Confidence interval; AST- Aspartate transaminase; ALT- Alanine transaminase; OR-odds ratio; CI- confidence interval.

genotype is often associated with high enzyme activity and high production of hepatotoxins (Roy et al. 2008, Tostmann et al. 2008), which corroborates our results, where patients with $R s a \mathrm{I}$ wild-type had higher liver enzyme levels after start of treatment. In a study with rats, administration of INH increased plasma concentrations of hydrazine and CYP2E1 activity, sometimes leading to hepatotoxicity (Yue et al. 2004). In another study with rats, the results suggested that CYP2E1 null is not involved with hepatotoxicity when INH is prescribed. (Cheng et al. 2013). In agreement with the study performed by Cho (Cho et al. 2007), we found no direct association between CYP2E1 polymorphisms and hepatotoxicity.

The CYP2E1 frequencies observed in our study are more similar to those found in EuropeanAmericans of European descent $(92 \% * 1 \mathrm{~A} / * 1 \mathrm{~A}$, $7 \% * 1 \mathrm{~A} / * 5 \mathrm{~B}$ and $1 \% * 5 \mathrm{~B} / * 5 \mathrm{~B}$ for $R s a \mathrm{I} / P s t \mathrm{I}$; $10 \% * 1 \mathrm{~A}$ and $90 \% * 6$ for DraI) (Roy et al. 2008). Polymorphisms in CYP2E1 are present at higher frequencies in Asians than any other populations (Garte et al. 2001), with a frequency of about $20-30 \%$ of the $* 5 B$ allele (Khan et al. 2009). According to the meta-analysis study by Cai (Cai et al. 2012) the NAT2 slow genotypes, $C Y P 2 E 1^{*} 1 \mathrm{~A}$ and GSTM1 null have a modest effect on the genetic susceptibility to hepatotoxicity. Another study reported that the administration of the flavonoid quercetin could neutralize the hepatotoxicity mediator CYP2E1 (Tang et al., 2013).

GSTS are a superfamily of enzymes involved in a range of biological detoxification processes. Whole GSTM1 and GSTT1 genes show high percentage of deletion in the human population (Bolt and Thier, 2006) and this is expected to contribute to interindividual differences in response to xenobiotics (Hayes et al. 2005). GSTM1 and GSTT1 deletions are the best choices for druginduced liver injury in association studies (Roy et al. 2001, Hussain et al. 2003, Leiro et al. 2008, Huang, 2010).

In our study, GSTM1 was deleted in almost $43 \%$ of the population, comparable to that observed in studies with Hispanic and EuropeanAmerican populations (Leiro et al. 2008, Roy et al. 2008). GSTT1 was deleted in $12.4 \%$ of the present population, a lower frequency than the one commonly described in European-American and Brazilian populations (Gaspar et al. 2004, Kvitko 
et al. 2006, Roy et al. 2008, Magno et al. 2009), but similar to Hispanic and Scandinavian populations (Garte et al. 2001, Roy et al. 2008). Data showed some associations between GSTT1 (Leiro etal.2008) and GSTM1 (Roy et al. 2001, Huang et al. 2007) null genotypes and hepatotoxicity. The GSTMI and GSTT1 may play a role in the susceptibility to drug-induced development of liver injury, which occurs regardless of the type of drug used, being more prevalent in women (Lucena et al. 2008). In our study no such association was observed. A study carried out in São Paulo (SP-Brazil) and Maringá (PR-Brazil) concluded that in addition to NAT2 polymorphisms, CYP2E1 and GSTM1/ GSTT1 the use of CYP2E1 inhibitors contribute to susceptibility to mild alterations in liver enzymes in patients receiving anti-tuberculosis drug therapy (Forestiero et al. 2013).

Based on the study by Monteiro et al. (2012) GSTM1 null genotype and GSTT1 do not appear to play a major role in hepatic injury induced by anti-tuberculosis drugs in Brazil, although there has been evidence that GSTM1 is associated to toxicity intensity. As for the genotyping of GSTM1 and GSTT1 polymorphisms, a casecontrol and one Indian population found that both null genotypes seem to be associated with drug-induced hepatotoxicity (Chatterjee et al. 2010). It is widely known that Brazil has one of the most genetically-mixed populations in the world. However the southernmost state, Rio Grande do Sul, has had a singular colonization. Portuguese people from the Azores were the very first immigrants to arrive in the capital city, Porto Alegre, followed by immigrants from Spain, Italy and Germany. The gene pool also has the contribution of African slaves and Amerindians. This mix is hardly exclusive to the South of the country and genetics differences have been established by studies using ancestry informative markers (Callegari-Jacques et al. 2003, Marrero et al. 2007, Guerreiro-Junior et al. 2009).
The incidence of ATD-induced hepatitis in our study was $6.1 \%$. This incidence rate varies extensively in different populations, for instance, 9.7\% in Malaysia (Marzuki et al. 2008), 11.9\% in Spain (Fernández-Villar et al. 2004) and 3\% in Canada (Yee et al. 2003). After the joint analysis including genetic and clinical risk factors for ATDinduced hepatitis it was observed that HIV, female sex, extrapulmonary TB and NAT2 slow acetylator profile are risk factors in our population. Other risk factors were observed in other populations, such as female sex, older age and pre-existing liver diseases (B and $\mathrm{C}$ hepatitis) (Saukkonen et al. 2006), but in our study no association was observed with these factors. The recommendation to design a study excluding patients with liver injuries, in order to have a clear understanding of the anti-TB drug effect on the liver was not possible at present, due to the high number of affected patients.

In conclusion, our study indicated that NAT2 slow acetylator profile, HIV, extrapulmonary tuberculosis and female sex predispose an individual to ATD-induced hepatitis. Further studies with a higher number of hepatotoxicity cases and simultaneous analysis of more polymorphisms should be carried out in different ethnic populations and in different regions of Brazil.

\section{ACKNOWLEDGMENTS}

The authors wish to thank the trial participants for their consent and participation in the study, as well as the staff from Sanatorio Partenon Hospital for their assistance. This work was supported by the Conselho Nacional de Desenvolvimento Científico e Tecnológico (CNPq); Laboratório Exame, Novo Hamburgo, RS and PADCT/FEPPS.

\section{RESUMO}

Durante o tratamento para tuberculose (TB) um dos efeitos adversos mais graves é a hepatite induzida por drogas (ATD) que tem sido associada a mutações nos genes que codificam as enzimas metabolizadoras destas drogas. 
A terapia de seis meses é composta por isoniazida, (INH), rifampicina (RMP), pirazinamida (PZA) e etambutol (EMB). N-acetiltransferase 2 (NAT2), citocromo P450 2E1 (CYP2E1) e glutationa-S-transferase (loci GSTM1 e GSTT1) estão envolvidos no metabolismo da isoniazida, o fármaco mais tóxico no tratamento da TB. Este estudo foi desenhado para estimar a frequência dos polimorfismos nos genes CYP2E1, GSTM1 e GSTT1 que estão relacionados com a resposta à essas drogas, e também identificar fatores clínicos de risco para ATD. Foram incluídos no estudo 245 pacientes brasileiros em tratamento para TB que foram genotipados utilizando a reação em cadeia de polímeras e sequenciamento dos polimorfismos. As frequências de alelos polimórficos CYP2E1 Rsal, Dral e PstI encontradas forame $8 \%, 8,5 \%$ e $12 \%$, respectivamente. Os genes GSTM1 e GSTT1 estão ausentes em 42,9\% e $12,4 \%$ da população, respectivamente. Quinze pacientes $(6,1 \%)$ desenvolveram hepatotoxicidade. As características clínicas (HIV, sexo feminino e TB extrapulmonar) e NAT2 perfil de acetilação lenta estão em maior risco de ATD nesta população. Genótipo para GSTM1 e GSTT1 não mostrou nenhuma influência na resposta à droga.

Palavras-chave: Hepatotoxicidade, isoniazida, polimorfismos, tuberculose.

\section{REFERENCES}

AN HR, WU XQ, WANG ZY, ZHANG JX AND LIANG Y. 2012. NAT2 and CYP2E1 polymorphisms associated with antituberculosis drug-induced hepatotoxicity in Chinese patients. Clin Exp Pharmacol Physiol 39: 535-543.

Arif E, VibHuti A, Alam P, DeEPAK D, Singh B, ATHAR M AND PASHA MA. 2007. Association of CYP2E1 and NAT2 gene polymorphisms with chronic obstructive pulmonary disease. Clin Chim Acta 382: 37-42.

BÉNICHOU C. 1990. Criteria of drug-induced liver disorders. Report of an international consensus meeting. J Hepatol 11: 272-276.

Boccia S, De Lauretis A, Gianfagna F, Van DuiJn CM AND RICCIARDI G. 2007. CYP2E1PstI/RsaI polymorphism and interaction with tobacco, alcohol and GSTs in gastric cancer susceptibility: A meta-analysis of the literature. Carcinogenesis 28: 101-106.

BolT H AND THIER R. 2006. Relevance of the deletion polymorphisms of the glutathione S-transferases GSTT1 and GSTM1 in pharmacology and toxicology. Curr Drug Metab 7: 613-628.
CAi Y, Yi J, Zhou C AND SHEN X. 2012. Pharmacogenetic Study of Drug-Metabolising Enzyme Polymorphisms on the Risk of Anti-Tuberculosis Drug-Induced Liver Injury: A Meta-Analysis. PLoS One 7: e47769.

Callegari-Jacques SM, Grattapaglia D, Salzano FM, SAlAmoni SP, CROSSETti SG, FERrEIRA ME AND Hutz MH. 2003. Historical genetics: spatiotemporal analysis of the formation of the Brazilian population. Am J Hum Biol 15: 824-834.

Castelo Filho A ET AL. 2004. II Consenso Brasileiro de Tuberculose: Diretrizes Brasileiras para Tuberculose 2004. J Bras de Pneumol 30: s57-s86.

Chamorro JG, Castagnino JP, Musella RM, Nogueras M, Aranda FM, Frías A, Visca M, Aidar O, PERÉs S AND DE LARRAÑAGA GF. 2013. Sex, ethnicity, and slow acetylator profile are the major causes of hepatotoxicity induced by antituberculosis drugs. J Gastroenterol Hepatol 28: 323-328.

Chatterjee S, Lyle N, Mandal A And Kundu S. 2010. GSTT1 and GSTM1 gene deletions are not associated with hepatotoxicity caused by antitubercular drugs. J Clin Pharm Ther 35: 465-470.

Cheng J, Krausz KW, Li F, MA X AND GonZalez FJ. 2013. CYP2E1-dependent elevation of serum cholesterol, triglycerides, and hepatic bile acids by isoniazid. Toxicol Appl Pharmacol 266: 245-253.

CHO HJ, KoH WJ, RYU YJ, KI CS, NAM MH, Kim JW AND LEE SY. 2007. Genetic polymorphisms of NAT2 and CYP2E1 associated with antituberculosis drug-induced hepatotoxicity in Korean patients with pulmonary tuberculosis. Tuberculosis (Edinb) 87: 551-556.

CONDE M ET AL. 2009. III Brazilian Thoracic Association Guidelines on tuberculosis. J Bras Pneumol 35: 1018-1048.

EICHELBAUM M, INGELMAN-SUNDBERG M AND EVANS WE. 2006. Pharmacogenomics and individualized drug therapy. Annu Rev Med 57: 119-137.

Fernández-Villar A, SOPEÑa B, FERnÁNDEZ-Villar J, VÁZQUEZ-Gallardo R, UlloA F, LEIRO V, Mosteiro M AND PIÑEIRO L. 2004. The influence of risk factors on the severity of anti-tuberculosis drug-induced hepatotoxicity. Int J Tuberc Lung Dis 8: 1499-1505.

Forestiero FJ, Cecon L, Hirata MH, de Melo FF, CARdoso RF, CERDA A AND HiRATA RD. 2013. Relationship of NAT2, CYP2E1 and GSTM1/GSTT1 polymorphisms with mild elevation of liver enzymes in Brazilian individuals under anti-tuberculosis drug therapy. Clin Chim Acta 415: 215-219.

GARTE S ET AL. 2001. Metabolic gene polymorphism frequencies in control populations. Cancer Epidemiol Biomarkers Prev 10: 1239-1248.

Gaspar P, Moreira J, Kvitko K, Torres M, Moreira A AND WEIMER T. 2004. CYP1A1, CYP2E1, GSTM1, GSTT1, GSTP1, and TP53 polymorphisms: do they indicate susceptibility to chronic obstructive pulmonary disease and non-small-cell lung cancer? Genet Mol Biol 27:133-138. 
Guerreiro-Junior V, Bisso-MAChado R, MARrero A, HÜNEMEIER T, SALZANO F AND BORTOLINI MC. 2009. Genetic Signatures of parental contribution in black and white populations in Brazil. Genet Mol Biol 32: 1-11.

Hayashi S, Watanabe J AND KaWAJIRI K. 1991. Genetic polymorphisms in the 5 '-flanking region change transcriptional regulation of the human cytochrome P450IIE1 gene. J Biochem 110: 559-565.

HAYES JD, FLANAGAN JU AND JOWSEY IR. 2005. Glutathione transferases. Annu Rev Pharmacol Toxicol 45: 51-88.

HUANG YS. 2010. Tailored drug therapy for mitigating druginnduced liver injury: is this the era of geetic screening? Personalized Medicine 7: 5-8.

HuANG YS, CHERN HD, Su WJ, JC WU, ChANG SC, ChIANG CH, CHANG FY AND LEE SD. 2003. Cytochrome P450 2E1 genotype and the susceptibility to antituberculosis druginduced hepatitis. Hepatology 37: 924-930.

Huang YS, Su WJ, Huang YH, Chen CY, Chang FY, LIN HC AND LEE SD. 2007. Genetic polymorphisms of manganese superoxide dismutase, NAD (P) H: quinone oxidoreductase, glutathione S-transferase M1 and T1, and the susceptibility to drug-induced liver injury. J Hepatol 47: 128-134.

Hussain Z, KAR P AND HuSAIN SA. 2003. Antituberculosis drug-induced hepatitis: risk factors, prevention and management. Indian J Exp Biol 41: 1226-1232.

INGELMAN-SUNDBERG M. 2004. Human drug metabolising cytochrome P450 enzymes: properties and polymorphisms. Naunyn Schmiedebergs Arch Pharmacol 369: 89-104.

INGELMAN-SUNDBERG M, SIM SC, GOMEZ A AND RODRIGUEZANTONA C. 2007. Influence of cytochrome P450 polymorphisms on drug therapies: pharmacogenetic, pharmacoepigenetic and clinical aspects. Pharmacol Ther 116: 496-526.

Kato S, Shields PG, Caporaso NE, HoOver RN, Trump BF, Sugimura H, Weston A AND Harris CC. 1992. Cytochrome P450IIE1 genetic polymorphisms, racial variation, and lung cancer risk. Cancer Res 52: 6712-6715.

KHAN AJ, Ruwali M, ChOUdhuri G, MATHUR N, HuSAIN Q AND PARMAR D. 2009. Polymorphism in cytochrome $P 4502 E 1$ and interaction with other genetic risk factors and susceptibility to alcoholic liver cirrhosis. Mutat Res 664: 55-63.

Kvitko K, Gaspar PDA, TORres M AND Hutz M. 2006. CYP1A1, GSTM1, GSTT1 and GSTP1 polymorphisms in an Afro-Brazilian group. Genet Mol Biol 29: 613-616.

Leiro V, Fernández-Villar A, VAlVerde D, Constenla L, VÁZQueZ R, PIÑEIRO L AND GONZÁLEZ-Quintela A. 2008. Influence of glutathione S-transferase M1 and T1 homozygous null mutations on the risk of antituberculosis drug-induced hepatotoxicity in a Caucasian population. Liver Int 28: 835-839.

LIU R, YIN LH AND PU YP. 2007. Association of combined CYP2E1 gene polymorphism with the risk for esophageal squamous cell carcinoma in Huai'an population, China. Chin Med J (Engl) 120: 1797-1802.
LONG JC, Williams RC AND URBaneK M. 1995. An E-M algorithm and testing strategy for multiple-locus haplotypes. Am J Hum Genet 56: 799-810.

LUCENA MI ET AL. 2008. Glutathione S-Transferase M1 and T1 Null Genotypes Increase Susceptibility to Idiosyncratic Drug-Induced Liver Injury. Hepatology 48: 588-596.

MAGNO LA ET AL. 2009. Glutathione s-transferase variants in a brazilian population. Pharmacology 83: 231-236.

MAHMOUD BG, GHOZZI H, KAMOUN A, HAKIM A, HACHICHA H, HAMmami S, SAHNOUN Z, Zalila N, MAKNi H AND ZEGHAL K. 2012. Polymorphism of the $\mathrm{N}$-acetyltransferase 2 gene as a susceptibility risk factor for antituberculosis drug-induced hepatotoxicity in Tunisian patients with tuberculosis. Pathol Biol 60: 324-330.

MARRERO AR ET AL. 2007. Pre- and post-Columbian gene and cultural continuity: the case of the Gaucho from southern Brazil. Hum Hered 64: 160-171.

MarzUKI OA, FAUZI AR, AYOUB S AND KAMARUl IMRAN M. 2008. Prevalence and risk factors of anti-tuberculosis drug-induced hepatitis in Malaysia. Singapore Med J 49: 688-693.

Mayfield D, Mcleod G and Hall P. 1974. The CAGE questionnaire: validation of a new alcoholism screening instrument. Am J Psychiatry 131: 1121-1123.

Miller SA, DyKes DD AND Polesky HF. 1988. A simple salting out procedure for extracting DNA from human nucleated cells. Nucleic Acids Res 16: 1215.

Monteiro TP, El-JAick KB, JEOVANIO-SILVA AL, BRAsIL PE, COSTA MJ, ROLla VC AND CASTRO L. 2012. The roles of GSTM1 and GSTT1 null genotypes and other predictors in anti-tuberculosis drug-induced liver injury. J Clin Pharm Ther 37: 712-718.

Multiple Locus Haplotype Analysis. 1999. Computer program, Version 2.0. Bethesda: Laboratory of Neurogenetics (NIAAA), National Institute of Health.

Possuelo LG ET AL. 2008. Association of slow $\mathrm{N}$-acetyltransferase 2 profile and anti-TB drug-induced hepatotoxicity in patients from Southern Brazil. Eur J Clin Pharmacol 64: 673-681.

Roy B, Chowdhury A, Kundu S, SANTra A, Dey B, CHAKRABORTY M AND MAJUMDER P. 2001. Increased risk of antituberculosis drug-induced hepatotoxicity in individuals with glutathione S-transferase M1 'null' mutation. J Gastroenterol Hepatol 16: 1033-1037.

Roy PD, MAJUMder M AND Roy B. 2008. Pharmacogenomics of anti-TB drugs-related hepatotoxicity. Pharmacogenomics 9: 311-321.

SAUKKONEN JJ ET AL. 2006. An official ATS statement: hepatotoxicity of antituberculosis therapy. Am J Respir Crit Care Med 174: 935-952.

Stine JG, SATEESh P AND LewIS JH. 2013. Drug-Induced Liver Injury in the Elderly. Curr Gastroenterol Rep 15: 299.

SuAREZ-KuRTz G AND PENA SD. 2006. Pharmacogenomics in the Americas: the impact of genetic admixture. Curr Drug Targets 7: 1649-1658. 
TANG Y, TIAN H, Shi Y, GaO C, XING M, YanG W, BAO W, WANG D, LIU L AND YAO P. 2013. Quercetin suppressed CYP2E1-dependent ethanol hepatotoxicity via depleting heme pool and releasing CO. Phytomedicine 20: 699-704.

TeIXeIra RL, Morato RG, CABELlo PH, Muniz LM, Moreira AdA S, Kritski AL, Mello FC, Suffys PN, Miranda AB AND SANTOS AR. 2011. Genetic polymorphisms of NAT2, CYP2E1 and GST enzymes and the occurrence of antituberculosis drug-induced hepatitis in Brazilian TB patients. Mem Inst Oswaldo Cruz 106: 716-724.

Tostmann A, Boeree MJ, Aarnoutse RE, De Lange WC, VAN Der Ven AJ AND DeKhuiJzen R. 2008. Antitubeculosisr drug-induced hepatotoxicity: concise up-to-date review. J Gastroenterol Hepatol 23: 192-202.

VUILLEUMIER N ET AL. 2006. CYP2E1 genotype and isoniazidinduced hepatotoxicity in patients treated for latent tuberculosis. Eur J Clin Pharmacol 62: 423-429.

WAlker NF, Kliner M, Turner D, Bhagani S, Cropley I, Hopkins S AND LIPMAN M. 2009. Hepatotoxicity and antituberculosis therapy: time to revise UK guidance? Thorax 64: 918.
WATANABE J, HAYASHI S AND KAWAJIRI K. 1994. Different regulation and expression of the human CYP2E1 gene due to the RsaI polymorphism in the 5'-flanking region. J Biochem 116: 321-326.

Yee D, Valiquette C, Pelletier M, Parisien I, Rocher I AND MENZIES D. 2003. Incidence of serious side effects from first-line antituberculosis drugs among patients treated for active tuberculosis. Am J Respir Crit Care Med 167(11): 1472-1477.

YEW WW AND LEUNG CC. 2006. Antituberculosis drugs and hepatotoxicity. Respirology 11: 699-707.

YIMER G ET AL. 2011. Pharmacogenetic \& Pharmacokinetic Biomarker for Efavirenz Based ARV and Rifampicin Based Anti-TB Drug Induced Liver Injury in TB-HIV Infected Patients. PLoS One 6: e27810.

Yue J, Peng RX, YAng J, Kong R And LiU J. 2004. CYP2E1 mediated isoniazid-induced hepatotoxicity in rats. Acta Pharmacol Sin 25: 699-704. 